\title{
The Many Hats of Sonic Hedgehog Signaling in Nervous System Development and Disease
}

\author{
Yesser H. Belgacem *, Andrew M. Hamilton, Sangwoo Shim, Kira A. Spencer \\ and Laura N. Borodinsky * \\ Department of Physiology \& Membrane Biology and Institute for Pediatric Regenerative Medicine, Shriners \\ Hospital for Children Northern California, University of California Davis School of Medicine, Sacramento, \\ CA 95817, USA; andrewmichaelhamilton@gmail.com (A.M.H.); sshim4@gmail.com (S.S.); \\ kaspencer@ucdavis.edu (K.A.S.) \\ * Correspondence: yesser.belgacem-tellier@inserm.fr (Y.H.B.); lnborodinsky@ucdavis.edu (L.N.B.); \\ Tel.: +33-(0)4-91-82-81-40 (Y.H.B.); +1-916-453-2285 (L.N.B.)
}

Academic Editors: Henk Roelink and Simon J. Conway

Received: 5 October 2016; Accepted: 29 November 2016; Published: 10 December 2016

\begin{abstract}
Sonic hedgehog (Shh) signaling occurs concurrently with the many processes that constitute nervous system development. Although Shh is mostly known for its proliferative and morphogenic action through its effects on neural stem cells and progenitors, it also contributes to neuronal differentiation, axonal pathfinding and synapse formation and function. To participate in these diverse events, Shh signaling manifests differently depending on the maturational state of the responsive cell, on the other signaling pathways regulating neural cell function and the environmental cues that surround target cells. Shh signaling is particularly dynamic in the nervous system, ranging from canonical transcription-dependent, to non-canonical and localized to axonal growth cones. Here, we review the variety of Shh functions in the developing nervous system and their consequences for neurodevelopmental diseases and neural regeneration, with particular emphasis on the signaling mechanisms underlying Shh action.
\end{abstract}

Keywords: non-canonical Sonic hedgehog signaling; neuronal differentiation; calcium signaling; synapse formation; neurodevelopmental disorders; medulloblastoma; neural regeneration

\section{Introduction}

The highly complex nature of the central nervous system is not only due to the copious number of cells it is composed of, but also to the number and diversity of connections between these cells. Moreover, neural function relies on dynamic changes in synapse connectivity and strength. This dynamic complexity of the nervous system is present throughout development and into adulthood. Nevertheless, different developmental stages are characterized by sets of specific cellular events, and the temporal and spatial boundaries of the developmental processes that create the nervous system are critically important. These boundaries are established by tight regulation of neural cell proliferation, neural progenitor specification, neuronal differentiation, synapse formation and neural plasticity. Intrinsic and extrinsic factors regulate these events. One potentially simple mechanism of switching from one cellular process to the next would be to switch factors by upregulating the expression of a "new" one while downregulating the expression of the "old" one. However, this paradigm does not always seem to apply; Sonic hedgehog (Shh) is a prominent example of a protein that is expressed in both the incipient nervous system and in the adult brain, but whose role varies widely throughout development. Its function in the nervous system was once thought to be restricted to the promotion of neural stem cell proliferation and neural progenitor specification. More recent studies have challenged this idea by showing that Shh signaling targets many different types of neural 
cells and by providing evidence of the diversity of processes regulated by Shh. Indeed, Shh appears to serve diverse functions depending on the developmental stage and maturity of the neural cells in question.

Here, we review the many roles of Shh during nervous system development and the signaling mechanisms associated with them. We propose a model of Shh signal switching throughout development to accommodate the wide variety of tasks and adapt to the dynamic changes in neural cell function as the nervous system develops and matures.

\section{Neural Cell Proliferation}

Nervous system morphogenesis relies on the expansion of stem cells to provide the critical cell mass necessary for neural function. Production of neural cells is achieved by active proliferation of neural stem cells during development, an event promoted by canonical Shh signaling (Figure 1 and Table 1). This pathway is initiated when Hedgehog $(\mathrm{Hh})$ binding to the receptor Patched (Ptch) [1,2] releases inhibition on the co-receptor Smoothened (Smo) [3-5], which leads to upregulation of the activity of the transcriptional activators glioma-associated oncogene (Gli) factors [6,7]. Ectopic expression of Shh in the mouse embryonic spinal cord approximately doubles cell proliferation in the dorsal neural tube [8], while an increase in Gli1 levels in Nestin-expressing mouse neural progenitors increases precursor cell numbers in vivo, resulting in a larger brain and broader progenitor domains [9]. Shh/Gli proliferative activity is also apparent in the early postnatal mouse cerebellum, where Shh secreted by Purkinje cells promotes cerebellar granule cell precursor proliferation and prevents their differentiation [10]. In addition to Ptch, Shh proliferative action requires the Hh-binding protein Gas1 (growth arrest specific 1) and the co-receptor Boc (biregional cell-adhesion-molecule-related/downregulated by oncogenes (Cdon)-binding protein) in cerebellar granule neuron progenitors from three-day-old mice [11]. In certain structures of the postnatal and adult brain, neural stem cells continue to produce neurons. Proliferation of adult neural stem cells in mouse hippocampus depends on Shh [12], and Shh also inhibits programmed cell death, contributing to the maintenance of adult neural stem cell niches in the subventricular zone, the dentate gyrus and olfactory bulb [13]. Shh acting through Smo at the primary cilium is also necessary for the recruitment of dentate gyrus postnatal progenitors [14]. However, ablation of primary cilia during embryonic development does not disrupt neurogenesis in the ventricular-subventricular zone of neonatal mice, with the exception of the anterior ventral neural cell population [15], suggesting very specific zones of influence for Shh-regulated neuroproliferation. In the adult brain, neural stem cell proliferation and neurogenesis also appear to depend more on restricting the repressor activity of Gli3R than on the activator character of Gli transcription factors according to double-mutant experiments for Gli2 and Gli3 [16].

The mechanisms of Shh/Gli-driven promotion of neural cell proliferation involve the regulation of cell cycle kinetics and cell survival. Shh canonical signaling regulates the length of G1 phase and expression of the anti-apoptotic factor $B c l 2$ in the ventral neural tube of chick embryos [17]. Similarly, reciprocal inhibitory interaction between Gli1 and p53 in neural progenitors controls neural stem cell number by enhancing proliferation and restricting stem cell expansion, respectively [9]. Shh promotes neuroepithelial cell proliferation in the embryonic chick and mouse neural tube by controlling progression into the G2 phase through regulating the expression of cyclins E, A and B [18] (Table 1). Additionally, Gli activity is necessary for Wnt-dependent control of G1 phase length in neural progenitors through upregulation of cyclin D1 expression by tcf3/4 [18].

However, regulation of neural cell proliferation by Shh is not always positive. For instance, in the developing Xenopus retina, Hh signaling speeds up the cell cycle by reducing the length of G1 and G2 phases. This may contribute to regulating the conversion from slow-cycling stem cells to fast-cycling transient amplifying progenitors [19]. Similarly, in Drosophila postembryonic brain neuroblasts, high levels of Hh signaling cause premature neuroblast cell cycle exit and underproliferation, which has consequences on the timing of neurogenesis [20]. 


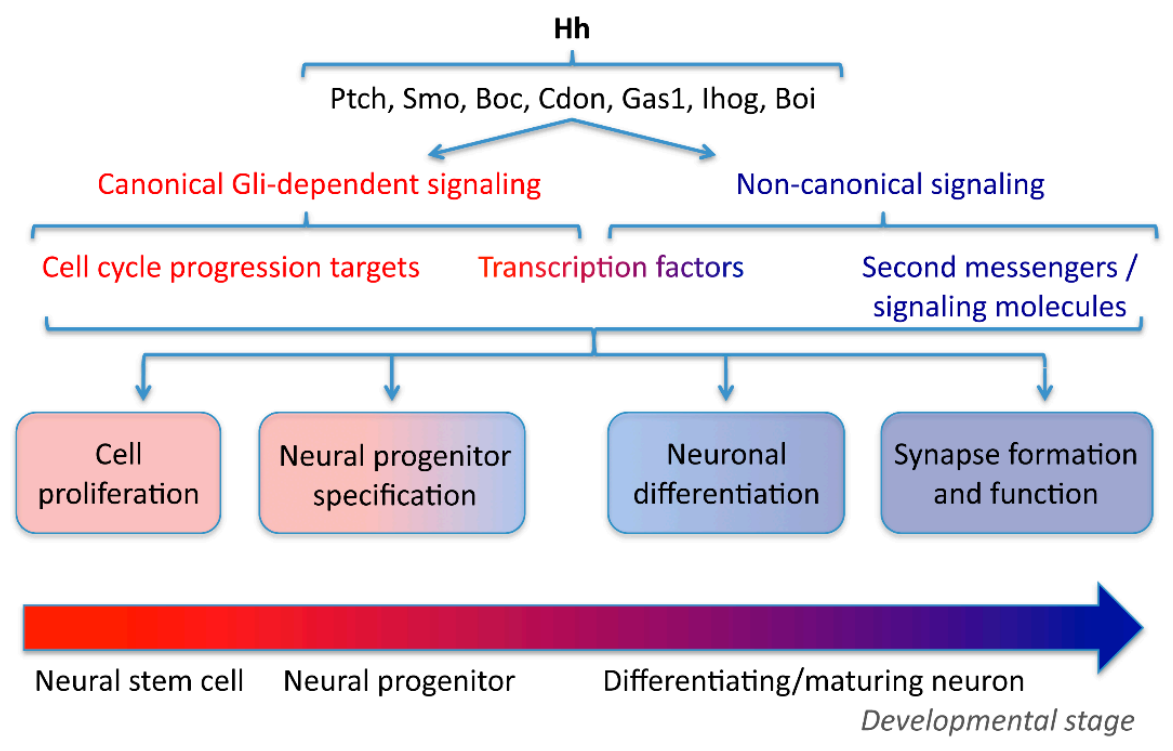

Figure 1. Hedgehog $(\mathrm{Hh})$ signaling spans nervous system development. Hh interacts with different receptors, co-receptors and interacting proteins to recruit canonical, glioma-associated oncogene (Gli)-dependent or non-canonical signaling pathways regulating the cellular events that encompass neural development and function. Boc: brother of cell adhesion molecule-related/down-regulated by oncogenes (Cdon); Boi: brother of interference hedgehog (Ihog); Gas1: growth-arrest specific gene-1; Ptch: Patched; Smo: Smoothened.

Table 1. Mechanisms and functions of canonical and non-canonical Hedgehog $(\mathrm{Hh})$ signaling in neural development.

\begin{tabular}{|c|c|c|c|c|c|c|}
\hline & \multicolumn{3}{|c|}{ Canonical } & \multicolumn{3}{|c|}{ Non-Canonical } \\
\hline & $\begin{array}{l}\text { Neural Cell } \\
\text { Proliferation }\end{array}$ & $\begin{array}{l}\text { Neural Progenitor } \\
\text { Specification }\end{array}$ & Axon Guidance & $\begin{array}{c}\text { Neuronal } \\
\text { Differentiation }\end{array}$ & $\begin{array}{c}\text { Axon } \\
\text { Guidance }\end{array}$ & Axon Guidance \\
\hline $\begin{array}{l}\text { Transcription } \\
\text { factors }\end{array}$ & Gli & Gli & Gli & cJun & $\begin{array}{l}\text { Transcription } \\
\text { independent }\end{array}$ & $\begin{array}{l}\text { Transcription } \\
\text { independent }\end{array}$ \\
\hline Targets & $\begin{array}{l}\text { Bcl2, P53, } \\
\text { cyclin A, B, } \\
\text { E, D1 }\end{array}$ & $\begin{array}{l}\text { Nkx2.2, Nkx6.1, } \\
\text { Pax6, Evx1, Phox2A, } \\
\text { Gata2, Fox2A, etc. }\end{array}$ & $\begin{array}{l}\text { (1) Slit } \\
\text { (2) Stromal } \\
\text { cell-derived } \\
\text { factor } 1\end{array}$ & Tlx3 & Src & \\
\hline Main roles & $\begin{array}{l}\text { Regulation } \\
\text { of cell cycle } \\
\text { progression } \\
\text { and cell } \\
\text { survival }\end{array}$ & $\begin{array}{l}\text { Spinal cord and } \\
\text { brain patterning } \\
\text { during } \\
\text { morphogenesis }\end{array}$ & $\begin{array}{l}\text { (1) Midline } \\
\text { crossing } \\
\text { forebrain } \\
\text { commissural } \\
\text { axons } \\
\text { (2) Retinal } \\
\text { ganglion cell } \\
\text { axon guidance }\end{array}$ & $\begin{array}{l}\text { Specification } \\
\text { of spinal } \\
\text { neuron } \\
\text { transmitter } \\
\text { phenotype }\end{array}$ & $\begin{array}{l}\text { Attractant } \\
\text { guidance } \\
\text { commissural } \\
\text { spinal axons }\end{array}$ & $\begin{array}{l}\text { (1) Repulsive guidance } \\
\text { commissural spinal axons } \\
\text { (2) Repulsive retinal } \\
\text { ganglion cell } \\
\text { axon guidance } \\
\text { (3) Repulsive guidance } \\
\text { enteric axons }\end{array}$ \\
\hline
\end{tabular}

?: Not yet determined or neural structure dependent. Bcl2: B-cell lymphoma 2; Boc: brother of cell adhesion molecule-related/down-regulated by oncogenes; cAMP: cyclic adenosine monophosphate; Evx1: even-skipped homeobox 1; Fox2A: forkhead box protein A2; Gas1: growth arrest specific 1; Gnaz: G Protein Subunit $\alpha$ Z; Hhip: hedgehog interacting protein; IP3: inositol 1,4,5-trisphosphate receptor type 3; Pax6: paired box 6; Phox2A: paired like homeobox 2A; Ptch: Patched; Smo: Smoothened; Src: proto-oncogene tyrosine-protein kinase; Tlx3: T-cell leukemia homeobox 3. 
The differences in Shh action on neural cell proliferation prompt the notion that the signaling pathways recruited by Shh are diverse and that the cellular outcome varies depending on the target cell and its maturational status, as well as on the molecular partners available at a given space and time. Indeed, Shh mitogenic and patterning functions are uncoupled when proteoglycan binding of Shh is perturbed. While this interaction is necessary for the proliferation of neural stem cells, it is not required for neural tube ventral patterning [21], providing an example of the versatility of Shh action depending on interactions with additional signaling molecules.

\section{Neural Progenitor Specification}

The transition from proliferation to differentiation in the developing nervous system occurs in a spatiotemporally-regulated manner (Figure 1). Whether Shh signaling participates in this transition remains unclear; however, profuse evidence has demonstrated that Shh function spans beyond its mitogenic role. The competence of the cell and its maturational status restrict the proliferative activity of Shh signaling, as suggested by the aforementioned study in which ectopic Shh expression in early fetal stages elicited enhanced neural cell proliferation, but not when Shh overexpression was implemented in the late stages of embryonic mouse nervous system formation [8]. Nevertheless, overexpression of Shh in late fetal stages, although not mitogenic, still halts the neural precursors in an undifferentiated state [8], indicating that Shh signaling may regulate the transitions between different neural cell maturational states.

One of the first functions attributed to the Shh pathway was its patterning role during tissue morphogenesis. In particular, Hh canonical signaling is responsible for specifying neural progenitors that in turn will give rise to different neuronal phenotypes in the developing nervous system. The patterning of ventral identities in the embryonic spinal cord has become a paradigm of the precise regulation exerted by the Shh canonical pathway [22-27]. Early studies demonstrated that blocking Shh signaling impairs the generation of motor neurons through its action during two critical periods; one in which neural plate cells are specified into ventralized progenitors and a later period during which Shh drives the differentiation of ventralized progenitors into motor neurons or interneurons [25]. The decision to adopt a certain neuronal identity is driven by a spatiotemporal code of transcription factor expression triggered by Shh levels and sensed by neural progenitors depending on their position relative to the ventrally-secreted morphogen. For instance, expression of $N k x 2.2$ in ventral neural progenitors is necessary for the neurogenesis of V3 ventral interneurons in the embryonic mouse spinal cord, while its expression limits the ventral boundaries for the generation of the motor neuron domain [24], which in turn depends on the ventral neural progenitor expression of Pax6 [26] (Table 1). However, neural progenitors are not static, as they migrate along the main axes of the neural tube, suggesting that they may sense different levels of Shh throughout development. In zebrafish embryos, this results in heterogeneous populations of specified progenitors that are afterwards sorted into sharply-bordered domains, including that for motor neuron progenitors [28]. Expression of specific cell adhesion molecules facilitates this cell sorting independently of canonical Shh signaling [28]. These findings agree with the discovery that translation of the Shh gradient into patterns of transcription factor expression for specifying neural progenitors occurs through the integration of Shh levels and signaling duration [29]. The interpretation of Shh gradient dynamics relies on a transcriptional network that can store the commands coming from integrated Shh signaling to define the specialization of ventral spinal cord progenitors [30]. Expression of many of these transcription factors is regulated by Gli activity directly [31-35], accounting for the central role of the canonical Shh pathway in the specification of neural progenitors. An interesting aspect of the activity of these transcription factors is that they are transcriptional repressors and as such are believed to repress the expression of alternative phenotypes, thus favoring the acquisition of a specific identity [31].

Glial progenitor cell specification is also dependent on Shh. The most prominent example is the oligodendrocyte lineage, for which the embryonic specification of their precursors depends on Shh derived from the floor plate and the notochord [36,37]. The basic helix-loop-helix transcription 
factors that are targeted in Shh-driven specification of oligodendrocyte progenitors are Olig1 and Olig2 in the mouse embryonic spinal cord [38]. Intriguingly, Olig2 is required for both motor neuron and oligodendrocyte progenitor specification, the former being specified earlier in the embryonic spinal cord than the latter [39]. A phosphorylation in Olig2 presumably mediated by cyclic adenosine monophosphate (cAMP)-dependent protein kinase A (PKA) participates in the switch from motor neuron to oligodendrocyte precursor [40].

In addition to the spinal cord, the developing brain is also patterned by Shh signaling. Shh is necessary and sufficient to define the size and shape of the midbrain arcs characterized by the expression of different combinations of the transcription factors Phox2A, Gata2, FoxA2 and the stripes expressing Pax6 or Evx1 in chick embryos [41] (Table 1). High rostroventral and low caudodorsal Shh specifies thalamic progenitor cells [42-45]. Interestingly, in the medial ganglionic eminence of mouse embryos, Shh signaling participates in a feed-forward mechanism triggered by the transcription factors Lhx6 and Lhx8, upregulating the expression of Shh, which in turn drives progenitors towards the phenotype of pallial interneurons and components of the septum and bed nucleus stria terminalis [46]. During corticogenesis, Shh canonical signaling regulates the specification of different subtypes of neural progenitors that will eventually provide the differentiated neurons to populate the cortical layers [47]. However, the level of Shh signaling is tightly regulated, and the predominant Gli form is the repressor Gli3R, the primary Gli antagonist of canonical Shh signaling [48-51]. This clamping of Shh canonical signaling at low levels is crucial and appears to be dependent on the negative regulator Suppressor of Fused ( $\mathrm{SuFu}$ ), since neural progenitor cells null for SuFu fail to maintain neural progenitor identity, and this conditional SuFu knockout mouse exhibits impaired corticogenesis [52].

\section{Neuronal and Glial Differentiation}

Pioneering studies on the invertebrate model organism Drosophila took the lead at demonstrating the role of Hh signaling in neuronal differentiation beyond its action in cell proliferation and progenitor specialization (Figure 1). Hh secreted by differentiated neurons triggers the differentiation of the cells next in line, propagating a wave of neuronal differentiation in the developing retina [53-55]. This mechanism is conserved in vertebrates like zebrafish, in which Shh derived from the first retinal neurons elicits a wave of neuronal differentiation extending across the vertebrate retina [56].

In the developing spinal cord, Shh-driven expression of the homeobox gene MNR2 is sufficient to initiate the motor neuron differentiation program that leads to the cholinergic phenotype and characteristic axonal routing [57]. Although the specification of the motor neuron phenotype starts in the motor neuron progenitor, some aspects of motor neuron differentiation continue in the post-mitotic neuron, such as acquiring motor neuron-specific axonal trajectory [58,59], which is activity dependent [59]. Ventral neurons in the forebrain are also responsive to Shh signaling through the expression of the transcription factor Islet-1 [60].

More recent studies have demonstrated roles for Shh in the aspects of neuronal identity that develop further down the path of progenitor specification, in the postmitotic neuron. Altering Shh signaling modifies the neural activity present in developing spinal neurons of Xenopus laevis embryos [61] (Figure 2a and Table 1). This activity manifests as $\mathrm{Ca}^{2+}$ spikes that last for $10 \mathrm{~h}$ during development concurrent with neuronal specialization [61-64]. Intriguingly, the frequency of $\mathrm{Ca}^{2+}$ spike activity is higher in ventral spinal neurons compared to their dorsal counterparts [62], resembling the ventrodorsal gradient for Shh in the embryonic spinal cord and opposing the dorsoventral gradient of bone morphogenetic protein (BMP), another morphogen acting inversely to Shh. Our studies reveal that Shh and BMPs regulate $\mathrm{Ca}^{2+}$ spike activity in an opposing manner; Shh increases $\mathrm{Ca}^{2+}$ spike frequency in spinal neurons, while BMPs decrease it $[61,64]$. In turn, electrical activity levels regulate the expression of neurotransmitter phenotype [62,65-68]. By recruiting $\mathrm{Ca}^{2+}$ spike activity as part of non-canonical signaling, Shh modifies neurotransmitter specification in developing spinal neurons [61]. Enhancing Shh signaling results in greater numbers of gamma-aminobutyric acid-ergic (GABAergic) spinal neurons, while blocking Shh signaling leads to fewer GABAergic neurons. These effects are 
prevented by suppressing Shh signaling-induced changes in $\mathrm{Ca}^{2+}$ spike activity, suggesting that $\mathrm{Ca}^{2+}$ signaling acts downstream of Shh action on neurotransmitter specification in developing neurons [61]. These findings suggest that the interaction between $\mathrm{Shh}$ and $\mathrm{Ca}^{2+}$-dependent electrical activity adds plasticity to the process of spinal neuron differentiation.
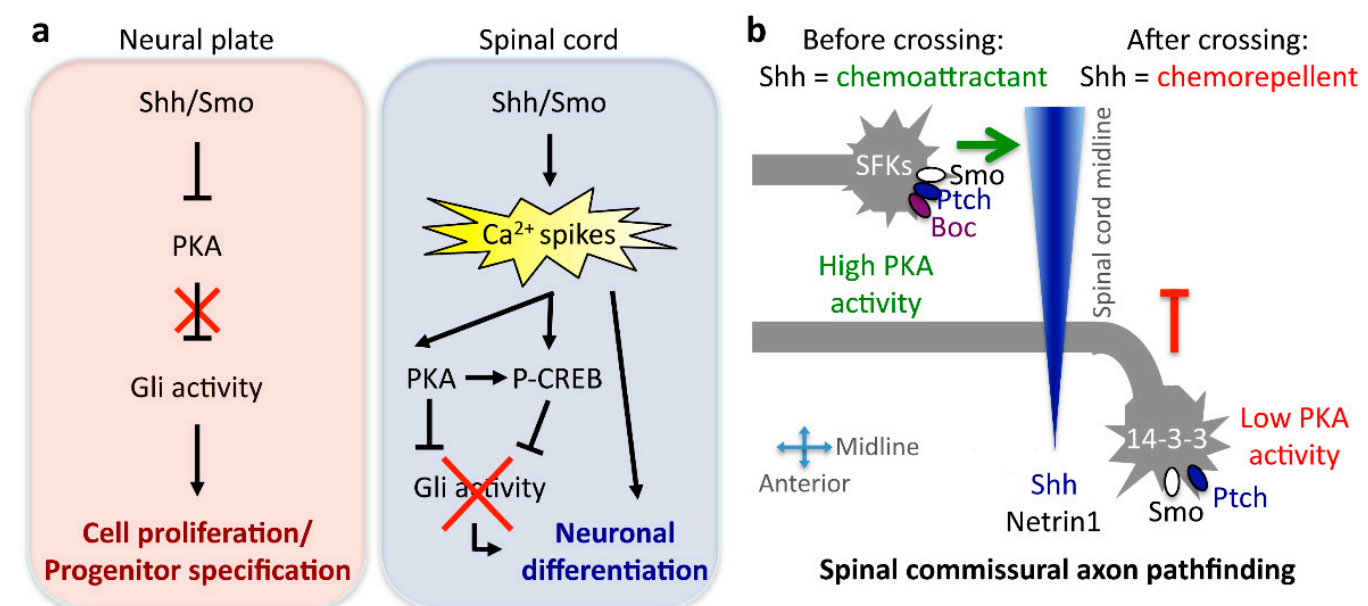

Figure 2. Mechanisms of Sonic hedgehog (Shh) signaling conversion during neural development. (a) Canonical Gli signaling is recruited in the developing neural plate, leading to neural stem cell proliferation and neural progenitor specification. The transition from neural plate to spinal cord in Xenopus laevis embryos is accompanied by a switch in Shh signaling from Gli to $\mathrm{Ca}^{2+}$ spike activity dependent, which results in the recruitment of protein kinase A (PKA) and the shutting off of Gli transcriptional activity in the differentiating neuron. (b) Shh action changes when commissural spinal axons cross ventrally the midline from chemoattractant to chemorepellent due to differential, growth cone-localized signaling in mouse embryos. The mediolateral and posteroanterior Shh gradient is represented in blue. P-CREB: phosphorylated cyclic adenosin monophosphate response element-binding protein.

Shh action is also relevant for glial differentiation as shown in a recent study in the developing and adult cerebellar cortex of the mouse. There, Shh produced by the neuronal populations of Purkinje and cerebellar granule cells determines the acquisition of Bergmann glial cell or velate astrocyte identities, through the regulation of the expression of specific glutamate transporters and receptors and the potassium channel Kir4.1 [69]. This study further challenges the concept that both neurons and glial cell differentiation are fully determined by a hardwired developmental program. Instead, this demonstrates that neurons, through Shh signaling, regulate their own cellular environment by dynamically changing the physiological properties of glial cells [69].

\section{Axon Guidance}

Another important functional feature of differentiating neurons is their axonal trajectory, which enables the establishment of appropriate connections with target cells. In zebrafish, Shh signaling regulates the expression of Netrin1, a known axon guidance molecule expressed by the floor plate and anterior ventral neural tube [70]. Shh effect on axon guidance is not limited to transcriptional regulation of expression of guidance cues; rather, Shh itself functions as a guidance cue by acting as a chemoattractant for commissural spinal axons in their trajectory towards the floor plate before midline crossing [71]. Attraction of commissural axons by Shh is transcription independent and Smo and Boc dependent, and leads to the activation of Src family kinases through a non-canonical signaling pathway [72,73]. Interestingly, this signaling is recruited at the growth cone of the commissural axon in a synergistic manner when both guidance cues, Netrin1 and Shh, are present, serving as a signaling mechanism for the integration of multiple cues [74]. Spinal commissural axons need 
to travel rostrally after crossing the midline, and this trajectory is also regulated by Shh, although instead of acting as a chemoattractant, here it acts as a chemorepellent for post-commissural spinal axons $[75,76]$. In chick embryos, the repulsive postcommissural axon guidance is driven through a Ptch- and Smo-independent mechanism mediated by hedgehog interacting protein (Hhip) [75]. In contrast, in the mouse embryonic spinal cord, genetic experiments showed that Hhip is dispensable for Shh-mediated repulsion, while Smo is required for Shh chemorepulsive action [76]. Moreover, the switch in commissural axon responsiveness to Shh is dependent on the developmentally-regulated expression of 14-3-3 proteins that regulate the activity of binding partners, such as PKA, resulting in decreased PKA activity in post-crossing axonal growth cones [76] (Figure 2b).

The Shh effects on axon guidance are also apparent in retinal ganglion cells. First, it was shown that axonal growth was negatively affected by Shh when growing towards the diencephalic ventral midline in the chick embryo [77]. Further studies showed that in vitro exposure to low and high levels of Shh attracts or repels retinal ganglion cell axons from chick embryos, and in vivo overexpression or inhibition of Shh both result in loss of centrally-directed retinal ganglion cell axon projections towards the optic disc [78]. In mice, Shh repels retinal ganglion cell axons, an action mediated by Boc and necessary for the normal segregation of these projections at the optic chiasm [79]. Shh-driven axon guidance can also be indirect, through regulating the expression of factors directly involved in axon guidance; these factors include Slit guidance molecules, which regulate the zebrafish forebrain midline crossing of postoptic commissural axons [80], and the chemokine pathway protein stromal cell-derived factor 1, which is expressed in the optic stalk in a Shh-dependent manner and is necessary for regulating the guidance of retinal ganglion cell axons [81].

In addition to central nervous system axons, Shh regulates the axonal trajectory of enteric neurons that innervate the smooth muscle in the gastrointestinal system. Here, Shh action consists of repelling enteric axons from projecting towards the central villi, allowing for tubular innervation of the gut wall in mouse embryos [82]. In this case, the signaling downstream of Shh includes the binding partner Gas1 and Smo expressed in enteric neurons, which in turn recruit the G protein $\alpha$ Z [82].

All of these studies demonstrate that Shh signaling through noncanonical mechanisms targets postmitotic differentiating neurons to regulate a number of traits, including neurotransmitter phenotype specialization, axonal morphology and axon guidance.

\section{Synapse Formation and Plasticity}

Once axons reach their targets, they establish synapses, which constitute the circuitry that enables neural network function (Figure 1). During Drosophila visual system development, Hh is delivered from photoreceptor axons to the lamina ganglion layer, inducing differentiation of their synaptic partners, the lamina neurons. Hedgehog is localized to axons, growth cones and synapses by a conserved motif in the hedgehog C-terminus [83]. The establishment of the retinotopic map through the formation of specific synapses relies on Hh-induced expression of the transcription factor Single-minded in lamina neurons, which enables association between the pre- and post-synapse by as yet unclear mechanisms [84]. Another subset of synapses in which partners are matched through Hh signaling intervention are the connections between olfactory receptor neurons and their glomerular targets in the Drosophila brain. First, Hh leads to differential Ptch expression in peripheral sensory organ precursors, which leads to olfactory neurons with different responsiveness to hedgehog derived from the brain [85]. Hence, in a second step of Hh intervention, only olfactory neurons expressing low levels of Ptch will depend on Hh derived from brain neurons for their axonal targeting through recruitment of Smo and the coreceptor Interference hedgehog (Ihog), a mechanism not available in high Ptch-expressing olfactory neurons due to strong inhibition of Smo [85].

Hh signaling components present in axonal terminals and postsynaptic specializations seem to be an aspect conserved across species. In addition to Drosophila, Smo is found presynaptically in close proximity to synaptic vesicles in the hippocampal mossy fibers of adult mice [86], and in the rat hippocampus, Ptch and Smo localize to processes and growth cones in developing neurons and 
in dendrites, dendritic spines and postsynaptic sites of the mature hippocampus [87]. Shh is present in inhibitory and excitatory synapses in the region I and III of hippocampus proper (CA1 and CA3) and dentate gyrus of the adult rat hippocampus, in pre- and post-synaptic neurons in the vicinity of the active zone, but in distinctly extrasynaptic sites [88]. Shh is also expressed in layer V corticofugal projection neurons, and its coreceptor Boc is expressed in local and callosal projection neurons of layer II/III, whose axons synapse onto subcortical projection neurons [89]. Moreover, the number of synapses formed onto layer $\mathrm{V}$ neurons and the strength of these synapses depend on expression of Shh and Boc, respectively [89], indicating the relevance of Shh signaling for synapse formation and function in vertebrates. In agreement with these findings, presynaptic terminals of cultured hippocampal neurons increase in size upon Shh exposure, resulting in increased frequency of miniature postsynaptic currents [90].

\section{Interactions of Shh with Other Signaling Pathways in the Nervous System}

Shh as a developmental factor for the nervous system is not spatiotemporally isolated, but rather acts concurrently with numerous cues and signaling pathways that dynamically change as the neural tissue develops and matures. Hence, Shh signaling is subjected to modulation by other developmentally-regulated pathways, which may even change Shh signaling's own action in the developing nervous system. Indeed, for Shh to participate seamlessly in the diverse, and sometimes contrasting, cellular events referred to in the above sections as nervous system development progresses, Shh activity needs to change with the maturational status of the neural cell. Here, we review some of the most prominent interactions of Shh with other signaling pathways and the modifications that result in the mechanisms of action for Shh signaling itself during nervous system development (Figure 3).

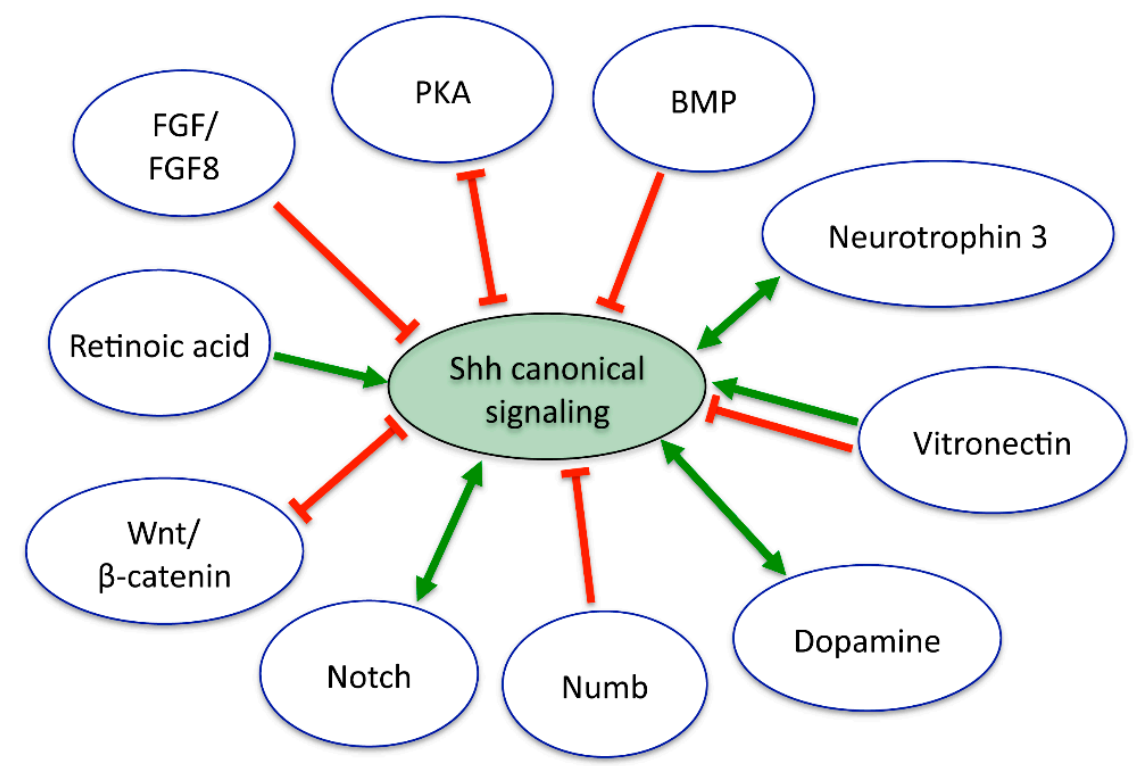

Figure 3. Multiple interactions between Shh and concurrent developmental cues modulate the Shh canonical signaling. Red and green arrows represent antagonistic and synergistic interactions, respectively. Double arrows represent feedback loops. See the text for details.

Rostrally to vertebrate mid-diencephalon, BMP7 and Shh are expressed from the same prechordal mesoderm and act on neural cells coordinately to induce the differentiation of rostral diencephalic ventral midline cells. BMP7 modifies Shh action by shifting the specification towards rostral phenotypes that otherwise, in the absence of BMP7, differentiate into Shh-producing floor plate cells [91]. In chick neural plate explants, BMP signaling modifies the responses of neural cells to Shh by inducing a ventral-to-dorsal switch, antagonistic activity that is modulated in vivo by the expression of BMP inhibitors along with Shh in structures ventral to the neural tube, like the notochord [92]. Another 
example of signaling interaction demonstrated through in vitro and ex vivo studies from mouse embryonic spinal cord is the synergy between Shh and neurotrophin 3 on motor neuron differentiation, through the regulation of Islet1 expression [93]. Accordingly, neurotrophin 3 knockout mice lack the subclass of fusimotor neurons, which make up $30 \%-40 \%$ of total spinal motor neurons [94]. These findings suggest that the differentiation of some subclasses of motor neurons requires interaction between Shh and neurotrophin 3 [93].

Since most of the transcription factors regulated by Shh are repressors of gene transcription, it is essential to consider that additional signaling pathways must be needed for the induction of a specific phenotype. Indeed, retinoic acid signaling is required for Shh-dependent motor neuron differentiation, while FGF8 downregulates the expression of Shh-induced repressors [95]. Another synergistic partner of Shh is the extracellular matrix protein Vitronectin, which is coexpressed with Shh in the chick notochord, floor plate and ventral neural tube and enhances the differentiation into motor neurons of cultured neuroepithelial cells only when coincubated with Shh, presumably by optimizing Shh presentation to target cells [96]. In contrast, in cerebellar granule cells grown in vitro, Vitronectin overrides the Shh proliferative signal to induce neuronal differentiation by recruiting the transcription factor cyclic-AMP responsive element-binding protein (CREB) [97]. Similarly, FGF promotes differentiation of cerebellar granule neurons in vivo and in vitro by recruiting ERK and JNK kinases and preventing Gli activity, thus abolishing Shh-induced proliferation. Moreover, FGF stops proliferation of patched mutant mice-derived tumor cells [98]. In some cases, the interaction between Shh and other signaling factors follows parallel pathways until they intersect at the level of transcriptional regulation, as illustrated by the establishment of thalamic neuron identity defined by a balance of transcription factor expression; thalamic Wnt/ $\beta$-catenin signaling results in the expression of Neurogenin1/2, while its repressor Nkx2.2 is driven by Shh-Gli signaling, defining the domains of thalamic neuron progenitors through mutual regulation of the transcriptional network [99].

Canonical Gli-dependent Shh signaling is also negatively regulated by PKA, and in the mouse neural tube, this regulation is implemented at the basal body of the primary cilium [100]; thus, pathways that inhibit PKA activity may enhance Gli activity. One interesting example of this interaction is the dopaminergic innervation from the brainstem that promotes motor neuron specification at the expense of V2 interneurons in the embryonic zebrafish spinal cord. This interaction between dopaminergic and Shh canonical signaling happens through activation of D4a dopamine receptors in pre-motor neuron progenitors that inhibit adenylate cyclase, lowering cAMP levels and inhibiting PKA. This results in Gli2 upregulation and increases the number of spinal motor neurons in the developing zebrafish [101]. A similar mechanism is activated upon injury when upregulated dopamine signaling promotes motor neuron regeneration by enhancing Shh signaling [101].

Another interesting type of interaction of signaling pathways with Shh emerges from regulating the localization of Shh signaling components (Table 1). Notch signaling inhibits Ptch localization to the primary cilium, allowing for Smo translocation to this subcellular compartment for full activation of Gli transcription factors, synergizing with Shh activity in regulating neural tube cell specification [102]. In contrast, Numb exerts an antagonistic role on Gli transcriptional activity by binding and targeting Gli to the proteasome-dependent degradation pathway through E3-ubiquitin ligase Itch during cerebellar granule cell progenitor differentiation [103]. Additionally, Notch is known to maintain neural stem cell character and prevent neuronal differentiation and is also inhibited by Numb through ubiquitin-dependent processing of Notch1 [104]. Thus, the obligatory role of Numb in neurogenesis seems to rely on inhibiting Shh proliferative action and Notch signaling [102,105]. Multiple functions of Shh in nervous system proliferation, differentiation and patterning may be facilitated by coordinated regulation and crosstalk between other signaling pathways that include Notch, Numb, BMP and Wnt (Figure 3).

The examples of interacting signaling pathways reviewed thus far result in promoting or preventing the canonical Gli-driven Shh pathway. However, considering that Shh expression persists throughout development and adulthood exerting diverse functions, there is ample support for the 
model of Shh signaling switching from one pathway that promotes proliferation to others that enable differentiation, maturation and survival of neural cells. In addition to dynamic changes in canonical Shh signaling, Shh becomes engaged in other non-canonical signaling cascades as development progresses, a concept that we recently demonstrated in the embryonic Xenopus spinal cord. Gli expression and activity decrease abruptly during spinal cord development when transitioning from the neural plate to spinal cord in Xenopus embryos [106,107] and in mice, approximately $30 \mathrm{~h}$ post-headfold [30] in nine-day-old embryos [106]. This downregulation of Gli activity is concurrent with the appearance of $\mathrm{Ca}^{2+}$ spikes in embryonic Xenopus spinal neurons, the frequency of which is enhanced by Shh in a transcription-independent, phospholipase C- and transient receptor potential channel-dependent manner [61]. In turn, $\mathrm{Ca}^{2+}$ spikes enhance PKA activity, thus switching Shh action from inhibiting PKA activity in the neural plate to enhancing it in differentiating spinal neurons [107]. This results in a paradoxical turning off of Shh's own canonical Gli-driven signaling during spinal cord development and a switch in Shh signaling to a non-canonical electrical activity and PKA-mediated pathway. The mechanisms of this switch operate on several levels, through inhibiting Gli2 nuclear translocation, favoring Gli2 and Gli3 processing towards repressor forms, and by Shh-dependent activation of CREB, which in turn represses Gli1 expression [107] (Figure 2a).

\section{Neural Disease and Regeneration}

Given the many important roles that Shh plays during nervous system development, it is not surprising to find that altering Shh signaling contributes to serious neurodevelopmental diseases. Indeed, reduced canonical Shh signaling leads to holoprosencephaly [108], likely due to aberrant patterning and deficient neural cell proliferation. On the other hand, constitutive activation of this pathway by deficient Ptch function [109] underlies the occurrence of several cancers, including a subgroup of the pediatric brain tumor medulloblastoma [108,110]. An increase in Gli1 levels in neural progenitors enables the expansion of neural precursors and neural stem cells and represses expression of p53, an inhibitor of Gli1 activity [9]. The cerebellar granule neuron precursors seem to be responsible for originating the Shh-dependent medulloblastoma [111,112]. In addition to N-myc, a common proto-oncogene [113], another transcription factor that participates in the canonical Shh signaling-driven promotion of neuronal precursor expansion is Atoh1 [114]; Shh prevents Atoh1 degradation by the E3 ubiquitin ligase Huwe1, which results in medulloblastoma when knocked out in mice [115]. Opposing the Shh signaling-driven medulloblastoma cell proliferation and progression is the $G$ protein $G \alpha s$, which localizes to the primary cilium in granule neuron precursors and downregulates canonical Shh signaling through a cAMP-driven pathway [116]. One of the hallmarks and critical events in the progression of medulloblastoma is the loss of Ptch1 expression, which deregulates Shh signaling [117-119]. The Shh binding protein Boc is upregulated in medulloblastomas and contributes to the cerebellar granule cell precursor expansion by facilitating aberrantly high Shh signaling, which leads to increased CyclinD1 activity and Ptch1 loss of heterozygosity [120].

In stark contrast to the Shh-dependent overproliferation leading to cerebellar tumors lies the phenotype afflicting Down syndrome patients and the segmentally trisomic postnatal mouse model for Down syndrome (Ts65Dn), which exhibit a smaller cerebellum due to a reduction in the number of granule neurons [121-123]. In Ts65Dn mice, the reduction in granule neurons results from deficient Shh-dependent mitogenic signaling in cerebellar granule neuron precursors during early postnatal development [124]. In an in vitro model, neural precursor cells from the subventricular zone and hippocampus of Ts65Dn mice show reduced canonical Shh signaling, which appears to be rooted in overexpressed Ptch1 due to transcriptional activation of Ptch1 expression by the amyloid precursor protein intracellular domain (AICD), a transcription-promoting fragment of amyloid precursor protein [125]. Moreover, treating newborn trisomic mice with the Smo agonist SAG restores cerebellar granule cell proliferation in one-week-old pups [124] and normal cerebellar morphology in adults [126]. Remarkably, SAG treatment also rescues behavioral deficits dependent on hippocampal function in 
the Down syndrome mouse model and partially restores theta burst stimulation-induced long-term potentiation in hippocampal slices from these animals [126]. It follows that Down syndrome, as well as other neurodevelopmental disorders, may be responsive to therapeutic intervention targeted to Shh signaling.

Regeneration of damaged neural tissue relies on many cellular events characteristic of neural development. Thus, it is not unexpected to find that Shh appears to be a vital regulator of post-injury neural regeneration. Indeed, Shh and Smo expression are upregulated in facial motor neurons after facial nerve axotomy in adult rats, and cyclopamine, a Smo antagonist, leads to a decrease in the number of surviving motor neurons after injury [127]. Similarly, after zebrafish spinal cord transection, there is an increase in Shh expression in the floor plate and upregulation of Ptch1 and Smo in ependymoradial glial cells, as well as the number of cells expressing the pre-motor neuron markers Olig2, Nkx6.1 and Pax6, which results in motor neuron regeneration, an effect that is prevented by Smo inhibitor cyclopamine [128]. In mice, invasive injury to the somatosensory cortex results in a regenerative response from astrocytes as a consequence of an inflammation-induced reactive gliosis that upregulates Shh signaling, which, in turn, leads to the generation of neural stem cells in the site of injury $[129,130]$. Moreover, enhancing Shh signaling by treating post-ischemic stroke mice with the Smo agonist purmorphamine is neuroprotective and improves recovery [131]. Intriguingly, recruitment of adult neural stem cells from the subventricular zone to demyelinating regions in the mouse forebrain is enhanced when the canonical Shh effector Gli1 is inhibited, while eliminating Smo-mediated signaling is detrimental for oligodendrocyte differentiation and remyelination [132]. These findings suggest that similarly to development, appropriate regeneration may require a switch from canonical to non-canonical Shh signaling.

\section{Conclusions}

Shh is a fascinating signaling molecule that is paramount in regulating nervous system development and function. Its relevance casts it as a target of interest for therapeutics of several neurodevelopmental diseases. However, every aspect of its signaling has some intricacy that demands close investigation, from its delivery and receptor molecules, to the subcellular localization of its signaling components, including the participation of the primary cilium in orchestrating Shh signaling in vertebrates, and the downstream pathways. Future challenges include understanding how Shh signaling transitions between functions during nervous system development and identifying the mechanisms that are targeted in disease and the regeneration of neural tissue. Taking into account that there is far more to Shh signaling than its mitogenic action and neural progenitor specification will allow for further discoveries of novel mechanisms mediated by Shh during neural development, disease and regeneration.

Acknowledgments: The work in the Borodinsky lab has been supported by the Basil O'Connor Starter Scholar Research Award Grant 5-FY09-131 from the March of Dimes Foundation, Klingenstein Foundation Award in Neuroscience, NSF 1120796, NIH-NINDS R01NS073055, and Shriners Hospital for Children 86500-NCA, 85220-NCA, 85300-NCA grants to Laura N. Borodinsky and by Shriners Hospital for Children postdoctoral fellowships to Yesser H. Belgacem and Andrew M. Hamilton.

Conflicts of Interest: The authors declare no conflict of interest.

\section{References}

1. Goodrich, L.V.; Milenkovic, L.; Higgins, K.M.; Scott, M.P. Altered neural cell fates and medulloblastoma in mouse patched mutants. Science 1997, 277, 1109-1113. [CrossRef] [PubMed]

2. Ingham, P.W.; Taylor, A.M.; Nakano, Y. Role of the Drosophila patched gene in positional signalling. Nature 1991, 353, 184-187. [CrossRef] [PubMed]

3. Alcedo, J.; Ayzenzon, M.; von Ohlen, T.; Noll, M.; Hooper, J.E. The Drosophila smoothened gene encodes a seven-pass membrane protein, a putative receptor for the Hedgehog signal. Cell 1996, 86, 221-232. [CrossRef] 
4. Van den Heuvel, M.; Ingham, P.W. Smoothened encodes a receptor-like serpentine protein required for Hedgehog signalling. Nature 1996, 382, 547-551. [CrossRef] [PubMed]

5. Chen, Y.; Struhl, G. Dual roles for Patched in sequestering and transducing Hedgehog. Cell 1996, 87, 553-563. [CrossRef]

6. Hynes, M.; Stone, D.M.; Dowd, M.; Pitts-Meek, S.; Goddard, A.; Gurney, A.; Rosenthal, A. Control of cell pattern in the neural tube by the zinc finger transcription factor and oncogene Gli-1. Neuron 1997, 19, 15-26. [CrossRef]

7. Dominguez, M.; Brunner, M.; Hafen, E.; Basler, K. Sending and receiving the Hedgehog signal: Control by the Drosophila Gli protein Cubitus interruptus. Science 1996, 272, 1621-1625. [CrossRef] [PubMed]

8. Rowitch, D.H.; St.-Jaques, B.; Lee, S.M.; Flax, J.D.; Snyder, E.Y.; McMahon, A.P. Sonic hedgehog regulates proliferation and inhibits differentiation of CNS precursor cells. J. Neurosci. 1999, 19, 8954-8965.

9. Stecca, B.; Ruiz i Altaba, A. A Gli1-p53 inhibitory loop controls neural stem cell and tumour cell numbers. EMBO J. 2009, 28, 663-676.

10. Wechsler-Reya, R.J.; Scott, M.P. Control of neuronal precursor proliferation in the cerebellum by Sonic hedgehog. Neuron 1999, 22, 103-114. [CrossRef]

11. Izzi, L.; Levesque, M.; Morin, S.; Laniel, D.; Wilkes, B.C.; Mille, F.; Krauss, R.S.; McMahon, A.P.; Allen, B.L.; Charron, F. Boc and Gas1 each form distinct Shh receptor complexes with Ptch1 and are required for Shh-mediated cell proliferation. Dev. Cell 2011, 20, 788-801. [CrossRef] [PubMed]

12. Lai, K.; Kaspar, B.K.; Gage, F.H.; Schaffer, D.V. Sonic hedgehog regulates adult neural progenitor proliferation in vitro and in vivo. Nat. Neurosci. 2003, 6, 21-27. [CrossRef] [PubMed]

13. Machold, R.; Hayashi, S.; Rutlin, M.; Muzumdar, M.D.; Nery, S.; Corbin, J.G.; Gritli-Linde, A.; Dellovade, T.; Porter, J.A.; Rubin, L.L.; et al. Sonic hedgehog is required for progenitor cell maintenance in telencephalic stem cell niches. Neuron 2003, 39, 937-950. [CrossRef]

14. Han, Y.G.; Spassky, N.; Romaguera-Ros, M.; Garcia-Verdugo, J.M.; Aguilar, A.; Schneider-Maunoury, S.; Alvarez-Buylla, A. Hedgehog signaling and primary cilia are required for the formation of adult neural stem cells. Nat. Neurosci. 2008, 11, 277-284. [CrossRef] [PubMed]

15. Tong, C.K.; Han, Y.G.; Shah, J.K.; Obernier, K.; Guinto, C.D.; Alvarez-Buylla, A. Primary cilia are required in a unique subpopulation of neural progenitors. Proc. Natl. Acad. Sci. USA 2014, 111, 12438-12443. [CrossRef] [PubMed]

16. Petrova, R.; Garcia, A.D.; Joyner, A.L. Titration of GLI3 repressor activity by sonic hedgehog signaling is critical for maintaining multiple adult neural stem cell and astrocyte functions. J. Neurosci. 2013, 33, 17490-17505. [CrossRef] [PubMed]

17. Cayuso, J.; Ulloa, F.; Cox, B.; Briscoe, J.; Marti, E. The Sonic hedgehog pathway independently controls the patterning, proliferation and survival of neuroepithelial cells by regulating Gli activity. Development 2006, 133, 517-528. [CrossRef] [PubMed]

18. Alvarez-Medina, R.; Le Dreau, G.; Ros, M.; Marti, E. Hedgehog activation is required upstream of Wnt signalling to control neural progenitor proliferation. Development 2009, 136, 3301-3309. [CrossRef] [PubMed]

19. Locker, M.; Agathocleous, M.; Amato, M.A.; Parain, K.; Harris, W.A.; Perron, M. Hedgehog signaling and the retina: Insights into the mechanisms controlling the proliferative properties of neural precursors. Genes Dev. 2006, 20, 3036-3048. [CrossRef] [PubMed]

20. Chai, P.C.; Liu, Z.; Chia, W.; Cai, Y. Hedgehog signaling acts with the temporal cascade to promote neuroblast cell cycle exit. PLoS Biol. 2013, 11, e1001494. [CrossRef] [PubMed]

21. Chan, J.A.; Balasubramanian, S.; Witt, R.M.; Nazemi, K.J.; Choi, Y.; Pazyra-Murphy, M.F.; Walsh, C.O.; Thompson, M.; Segal, R.A. Proteoglycan interactions with Sonic Hedgehog specify mitogenic responses. Nat. Neurosci. 2009, 12, 409-417. [CrossRef] [PubMed]

22. Wijgerde, M.; McMahon, J.A.; Rule, M.; McMahon, A.P. A direct requirement for Hedgehog signaling for normal specification of all ventral progenitor domains in the presumptive mammalian spinal cord. Genes Dev. 2002, 16, 2849-2864. [CrossRef] [PubMed]

23. Briscoe, J.; Pierani, A.; Jessell, T.M.; Ericson, J. A homeodomain protein code specifies progenitor cell identity and neuronal fate in the ventral neural tube. Cell 2000, 101, 435-445. [CrossRef]

24. Briscoe, J.; Sussel, L.; Serup, P.; Hartigan-O'Connor, D.; Jessell, T.M.; Rubenstein, J.L.; Ericson, J. Homeobox gene Nkx2.2 and specification of neuronal identity by graded Sonic hedgehog signalling. Nature 1999, 398, 622-627. [PubMed] 
25. Ericson, J.; Morton, S.; Kawakami, A.; Roelink, H.; Jessell, T.M. Two critical periods of Sonic hedgehog signaling required for the specification of motor neuron identity. Cell 1996, 87, 661-673. [CrossRef]

26. Ericson, J.; Rashbass, P.; Schedl, A.; Brenner-Morton, S.; Kawakami, A.; van Heyningen, V.; Jessell, T.M.; Briscoe, J. Pax6 controls progenitor cell identity and neuronal fate in response to graded Shh signaling. Cell 1997, 90, 169-180. [CrossRef]

27. Ericson, J.; Thor, S.; Edlund, T.; Jessell, T.M.; Yamada, T. Early stages of motor neuron differentiation revealed by expression of homeobox gene Islet-1. Science 1992, 256, 1555-1560. [CrossRef] [PubMed]

28. Xiong, F.; Tentner, A.R.; Huang, P.; Gelas, A.; Mosaliganti, K.R.; Souhait, L.; Rannou, N.; Swinburne, I.A.; Obholzer, N.D.; Cowgill, P.D.; et al. Specified neural progenitors sort to form sharp domains after noisy Shh signaling. Cell 2013, 153, 550-561. [CrossRef] [PubMed]

29. Dessaud, E.; Ribes, V.; Balaskas, N.; Yang, L.L.; Pierani, A.; Kicheva, A.; Novitch, B.G.; Briscoe, J.; Sasai, N. Dynamic assignment and maintenance of positional identity in the ventral neural tube by the morphogen Sonic hedgehog. PLoS Biol. 2010, 8, e1000382. [CrossRef] [PubMed]

30. Balaskas, N.; Ribeiro, A.; Panovska, J.; Dessaud, E.; Sasai, N.; Page, K.M.; Briscoe, J.; Ribes, V. Gene regulatory logic for reading the Sonic Hedgehog signaling gradient in the vertebrate neural tube. Cell 2012, 148, 273-284. [CrossRef] [PubMed]

31. Nishi, Y.; Zhang, X.; Jeong, J.; Peterson, K.A.; Vedenko, A.; Bulyk, M.L.; Hide, W.A.; McMahon, A.P. A direct fate exclusion mechanism by Sonic hedgehog-regulated transcriptional repressors. Development 2015, 142, 3286-3293. [CrossRef] [PubMed]

32. Peterson, K.A.; Nishi, Y.; Ma, W.; Vedenko, A.; Shokri, L.; Zhang, X.; McFarlane, M.; Baizabal, J.M.; Junker, J.P.; van Oudenaarden, A.; et al. Neural-specific Sox2 input and differential Gli-binding affinity provide context and positional information in Shh-directed neural patterning. Genes Dev. 2012, 26, 2802-2816. [CrossRef] [PubMed]

33. Lei, Q.; Jeong, Y.; Misra, K.; Li, S.; Zelman, A.K.; Epstein, D.J.; Matise, M.P. Wnt signaling inhibitors regulate the transcriptional response to morphogenetic Shh-Gli signaling in the neural tube. Dev. Cell 2006, 11, 325-337. [CrossRef] [PubMed]

34. Oosterveen, T.; Kurdija, S.; Alekseenko, Z.; Uhde, C.W.; Bergsland, M.; Sandberg, M.; Andersson, E.; Dias, J.M.; Muhr, J.; Ericson, J. Mechanistic differences in the transcriptional interpretation of local and long-range Shh morphogen signaling. Dev. Cell 2012, 23, 1006-1019. [CrossRef] [PubMed]

35. Wang, H.; Lei, Q.; Oosterveen, T.; Ericson, J.; Matise, M.P. Tcf/Lef repressors differentially regulate Shh-Gli target gene activation thresholds to generate progenitor patterning in the developing CNS. Development 2011, 138, 3711-3721. [CrossRef] [PubMed]

36. Pringle, N.P.; Yu, W.P.; Guthrie, S.; Roelink, H.; Lumsden, A.; Peterson, A.C.; Richardson, W.D. Determination of neuroepithelial cell fate: Induction of the oligodendrocyte lineage by ventral midline cells and Sonic hedgehog. Dev. Biol. 1996, 177, 30-42. [CrossRef] [PubMed]

37. Orentas, D.M.; Hayes, J.E.; Dyer, K.L.; Miller, R.H. Sonic hedgehog signaling is required during the appearance of spinal cord oligodendrocyte precursors. Development 1999, 126, 2419-2429. [PubMed]

38. Lu, Q.R.; Yuk, D.; Alberta, J.A.; Zhu, Z.; Pawlitzky, I.; Chan, J.; McMahon, A.P.; Stiles, C.D.; Rowitch, D.H. Sonic hedgehog-regulated oligodendrocyte lineage genes encoding bHLH proteins in the mammalian central nervous system. Neuron 2000, 25, 317-329. [CrossRef]

39. Takebayashi, H.; Nabeshima, Y.; Yoshida, S.; Chisaka, O.; Ikenaka, K.; Nabeshima, Y. The basic helix-loop-helix factor olig2 is essential for the development of motoneuron and oligodendrocyte lineages. Curr. Biol. 2002, 12, 1157-1163. [CrossRef]

40. Li, H.; de Faria, J.P.; Andrew, P.; Nitarska, J.; Richardson, W.D. Phosphorylation regulates OLIG2 cofactor choice and the motor neuron-oligodendrocyte fate switch. Neuron 2011, 69, 918-929. [CrossRef] [PubMed]

41. Agarwala, S.; Sanders, T.A.; Ragsdale, C.W. Sonic hedgehog control of size and shape in midbrain pattern formation. Science 2001, 291, 2147-2150. [CrossRef] [PubMed]

42. Kiecker, C.; Lumsden, A. Hedgehog signaling from the ZLI regulates diencephalic regional identity. Nat. Neurosci. 2004, 7, 1242-1249. [CrossRef] [PubMed]

43. Vieira, C.; Garda, A.L.; Shimamura, K.; Martinez, S. Thalamic development induced by Shh in the chick embryo. Dev. Biol. 2005, 284, 351-363. [CrossRef] [PubMed] 
44. Vue, T.Y.; Bluske, K.; Alishahi, A.; Yang, L.L.; Koyano-Nakagawa, N.; Novitch, B.; Nakagawa, Y. Sonic hedgehog signaling controls thalamic progenitor identity and nuclei specification in mice. J. Neurosci. 2009, 29, 4484-4497. [CrossRef] [PubMed]

45. Jeong, Y.; Dolson, D.K.; Waclaw, R.R.; Matise, M.P.; Sussel, L.; Campbell, K.; Kaestner, K.H.; Epstein, D.J. Spatial and temporal requirements for sonic hedgehog in the regulation of thalamic interneuron identity. Development 2011, 138, 531-541. [CrossRef] [PubMed]

46. Flandin, P.; Zhao, Y.; Vogt, D.; Jeong, J.; Long, J.; Potter, G.; Westphal, H.; Rubenstein, J.L. Lhx6 and Lhx8 coordinately induce neuronal expression of Shh that controls the generation of interneuron progenitors. Neuron 2011, 70, 939-950. [CrossRef] [PubMed]

47. Sousa, V.H.; Fishell, G. Sonic hedgehog functions through dynamic changes in temporal competence in the developing forebrain. Curr. Opin. Genet. Dev. 2010, 20, 391-399. [CrossRef] [PubMed]

48. Fotaki, V.; Yu, T.; Zaki, P.A.; Mason, J.O.; Price, D.J. Abnormal positioning of diencephalic cell types in neocortical tissue in the dorsal telencephalon of mice lacking functional Gli3. J. Neurosci. 2006, 26, 9282-9292. [CrossRef] [PubMed]

49. Palma, V.; Ruiz i Altaba, A. Hedgehog-GLI signaling regulates the behavior of cells with stem cell properties in the developing neocortex. Development 2004, 131, 337-345. [CrossRef] [PubMed]

50. Wang, H.; Ge, G.; Uchida, Y.; Luu, B.; Ahn, S. Gli3 is required for maintenance and fate specification of cortical progenitors. J. Neurosci. 2011, 31, 6440-6448. [CrossRef] [PubMed]

51. Wilson, S.L.; Wilson, J.P.; Wang, C.; Wang, B.; McConnell, S.K. Primary cilia and Gli3 activity regulate cerebral cortical size. Dev. Neurobiol. 2012, 72, 1196-1212. [CrossRef] [PubMed]

52. Yabut, O.R.; Fernandez, G.; Huynh, T.; Yoon, K.; Pleasure, S.J. Suppressor of fused is critical for maintenance of neuronal progenitor identity during corticogenesis. Cell Rep. 2015, 12, 2021-2034. [CrossRef] [PubMed]

53. Heberlein, U.; Singh, C.M.; Luk, A.Y.; Donohoe, T.J. Growth and differentiation in the Drosophila eye coordinated by hedgehog. Nature 1995, 373, 709-711. [CrossRef] [PubMed]

54. Heberlein, U.; Wolff, T.; Rubin, G.M. The TGF beta homolog dpp and the segment polarity gene hedgehog are required for propagation of a morphogenetic wave in the Drosophila retina. Cell 1993, 75, 913-926. [CrossRef]

55. Ma, C.; Zhou, Y.; Beachy, P.A.; Moses, K. The segment polarity gene hedgehog is required for progression of the morphogenetic furrow in the developing Drosophila eye. Cell 1993, 75, 927-938. [CrossRef]

56. Neumann, C.J.; Nuesslein-Volhard, C. Patterning of the zebrafish retina by a wave of Sonic hedgehog activity. Science 2000, 289, 2137-2139. [CrossRef] [PubMed]

57. Tanabe, Y.; William, C.; Jessell, T.M. Specification of motor neuron identity by the MNR2 homeodomain protein. Cell 1998, 95, 67-80. [CrossRef]

58. Eisen, J.S. Determination of primary motoneuron identity in developing zebrafish embryos. Science 1991, 252, 569-572. [CrossRef] [PubMed]

59. Hanson, M.G.; Landmesser, L.T. Normal patterns of spontaneous activity are required for correct motor axon guidance and the expression of specific guidance molecules. Neuron 2004, 43, 687-701. [CrossRef] [PubMed]

60. Ericson, J.; Muhr, J.; Placzek, M.; Lints, T.; Jessell, T.M.; Edlund, T. Sonic hedgehog induces the differentiation of ventral forebrain neurons: A common signal for ventral patterning within the neural tube. Cell 1995, 81, 747-756. [CrossRef]

61. Belgacem, Y.H.; Borodinsky, L.N. Sonic hedgehog signaling is decoded by calcium spike activity in the developing spinal cord. Proc. Natl. Acad. Sci. USA 2011, 108, 4482-4487. [CrossRef] [PubMed]

62. Borodinsky, L.N.; Root, C.M.; Cronin, J.A.; Sann, S.B.; Gu, X.; Spitzer, N.C. Activity-dependent homeostatic specification of transmitter expression in embryonic neurons. Nature 2004, 429, 523-530. [CrossRef] [PubMed]

63. Root, C.M.; Velazquez-Ulloa, N.A.; Monsalve, G.C.; Minakova, E.; Spitzer, N.C. Embryonically expressed GABA and glutamate drive electrical activity regulating neurotransmitter specification. J. Neurosci. 2008, 28, 4777-4784. [CrossRef] [PubMed]

64. Swapna, I.; Borodinsky, L.N. Interplay between electrical activity and bone morphogenetic protein signaling regulates spinal neuron differentiation. Proc. Natl. Acad. Sci. USA 2012, 109, 16336-16341. [CrossRef] [PubMed]

65. Marek, K.W.; Kurtz, L.M.; Spitzer, N.C. cJun integrates calcium activity and $t l x 3$ expression to regulate neurotransmitter specification. Nat. Neurosci. 2010, 13, 944-950. [CrossRef] [PubMed]

66. Demarque, M.; Spitzer, N.C. Activity-dependent expression of Lmx1b regulates specification of serotonergic neurons modulating swimming behavior. Neuron 2010, 67, 321-334. [CrossRef] [PubMed] 
67. Dulcis, D.; Spitzer, N.C. Illumination controls differentiation of dopamine neurons regulating behaviour. Nature 2008, 456, 195-201. [CrossRef] [PubMed]

68. Dulcis, D.; Jamshidi, P.; Leutgeb, S.; Spitzer, N.C. Neurotransmitter switching in the adult brain regulates behavior. Science 2013, 340, 449-453. [CrossRef] [PubMed]

69. Farmer, W.T.; Abrahamsson, T.; Chierzi, S.; Lui, C.; Zaelzer, C.; Jones, E.V.; Bally, B.P.; Chen, G.G.; Theroux, J.F.; Peng, J.; et al. Neurons diversify astrocytes in the adult brain through Sonic hedgehog signaling. Science 2016, 351, 849-854. [CrossRef] [PubMed]

70. Strahle, U.; Fischer, N.; Blader, P. Expression and regulation of a netrin homologue in the zebrafish embryo. Mech. Dev. 1997, 62, 147-160. [CrossRef]

71. Charron, F.; Stein, E.; Jeong, J.; McMahon, A.P.; Tessier-Lavigne, M. The morphogen Sonic hedgehog is an axonal chemoattractant that collaborates with Netrin-1 in midline axon guidance. Cell 2003, 113, 11-23. [CrossRef]

72. Yam, P.T.; Langlois, S.D.; Morin, S.; Charron, F. Sonic hedgehog guides axons through a noncanonical, Src-family-kinase-dependent signaling pathway. Neuron 2009, 62, 349-362. [CrossRef] [PubMed]

73. Okada, A.; Charron, F.; Morin, S.; Shin, D.S.; Wong, K.; Fabre, P.J.; Tessier-Lavigne, M.; McConnell, S.K. Boc is a receptor for Sonic hedgehog in the guidance of commissural axons. Nature 2006, 444, 369-373. [CrossRef] [PubMed]

74. Sloan, T.F.; Qasaimeh, M.A.; Juncker, D.; Yam, P.T.; Charron, F. Integration of shallow gradients of Shh and Netrin-1 guides commissural axons. PLoS Biol. 2015, 13, e1002119. [CrossRef] [PubMed]

75. Bourikas, D.; Pekarik, V.; Baeriswyl, T.; Grunditz, A.; Sadhu, R.; Nardo, M.; Stoeckli, E.T. Sonic hedgehog guides commissural axons along the longitudinal axis of the spinal cord. Nat. Neurosci. 2005, 8, 297-304. [CrossRef] [PubMed]

76. Yam, P.T.; Kent, C.B.; Morin, S.; Farmer, W.T.; Alchini, R.; Lepelletier, L.; Colman, D.R.; Tessier-Lavigne, M.; Fournier, A.E.; Charron, F. 14-3-3 proteins regulate a cell-intrinsic switch from Sonic hedgehog-mediated commissural axon attraction to repulsion after midline crossing. Neuron 2012, 76, 735-749. [CrossRef] [PubMed]

77. Trousse, F.; Marti, E.; Gruss, P.; Torres, M.; Bovolenta, P. Control of retinal ganglion cell axon growth: A new role for Sonic hedgehog. Development 2001, 128, 3927-3936. [PubMed]

78. Kolpak, A.; Zhang, J.; Bao, Z.Z. Sonic hedgehog has a dual effect on the growth of retinal ganglion axons depending on its concentration. J. Neurosci. 2005, 25, 3432-3441. [CrossRef] [PubMed]

79. Fabre, P.J.; Shimogori, T.; Charron, F. Segregation of ipsilateral retinal ganglion cell axons at the optic chiasm requires the Shh receptor Boc. J. Neurosci. 2010, 30, 266-275. [CrossRef] [PubMed]

80. Barresi, M.J.; Hutson, L.D.; Chien, C.B.; Karlstrom, R.O. Hedgehog regulated Slit expression determines commissure and glial cell position in the zebrafish forebrain. Development 2005, 132, 3643-3656. [CrossRef] [PubMed]

81. Stacher Horndli, C.; Chien, C.B. Sonic hedgehog is indirectly required for intraretinal axon pathfinding by regulating chemokine expression in the optic stalk. Development 2012, 139, 2604-2613. [CrossRef] [PubMed]

82. Jin, S.; Martinelli, D.C.; Zheng, X.; Tessier-Lavigne, M.; Fan, C.M. Gas1 is a receptor for Sonic hedgehog to repel enteric axons. Proc. Natl. Acad. Sci. USA 2015, 112, E73-E80. [CrossRef] [PubMed]

83. Chu, T.; Chiu, M.; Zhang, E.; Kunes, S. A C-terminal motif targets Hedgehog to axons, coordinating assembly of the Drosophila eye and brain. Dev. Cell 2006, 10, 635-646. [CrossRef] [PubMed]

84. Umetsu, D.; Murakami, S.; Sato, M.; Tabata, T. The highly ordered assembly of retinal axons and their synaptic partners is regulated by Hedgehog/Single-minded in the Drosophila visual system. Development 2006, 133, 791-800. [CrossRef] [PubMed]

85. Chou, Y.H.; Zheng, X.; Beachy, P.A.; Luo, L. Patterning axon targeting of olfactory receptor neurons by coupled hedgehog signaling at two distinct steps. Cell 2010, 142, 954-966. [CrossRef] [PubMed]

86. Masdeu, C.; Bernard, V.; Faure, H.; Traiffort, E.; Ruat, M. Distribution of Smoothened at hippocampal mossy fiber synapses. Neuroreport 2007, 18, 395-399. [CrossRef] [PubMed]

87. Petralia, R.S.; Schwartz, C.M.; Wang, Y.X.; Mattson, M.P.; Yao, P.J. Subcellular localization of Patched and Smoothened, the receptors for Sonic hedgehog signaling, in the hippocampal neuron. J. Comp. Neurol. 2011, 519, 3684-3699. [CrossRef] [PubMed]

88. Petralia, R.S.; Wang, Y.X.; Mattson, M.P.; Yao, P.J. Sonic hedgehog distribution within mature hippocampal neurons. Commun. Integr. Biol. 2011, 4, 775-777. [CrossRef] [PubMed] 
89. Harwell, C.C.; Parker, P.R.; Gee, S.M.; Okada, A.; McConnell, S.K.; Kreitzer, A.C.; Kriegstein, A.R. Sonic hedgehog expression in corticofugal projection neurons directs cortical microcircuit formation. Neuron 2012, 73, 1116-1126. [CrossRef] [PubMed]

90. Mitchell, N.; Petralia, R.S.; Currier, D.G.; Wang, Y.X.; Kim, A.; Mattson, M.P.; Yao, P.J. Sonic hedgehog regulates presynaptic terminal size, ultrastructure and function in hippocampal neurons. J. Cell Sci. 2012, 125, 4207-4213. [CrossRef] [PubMed]

91. Dale, J.K.; Vesque, C.; Lints, T.J.; Sampath, T.K.; Furley, A.; Dodd, J.; Placzek, M. Cooperation of BMP7 and $\mathrm{SHH}$ in the induction of forebrain ventral midline cells by prechordal mesoderm. Cell 1997, 90, $257-269$. [CrossRef]

92. Liem, K.F., Jr.; Jessell, T.M.; Briscoe, J. Regulation of the neural patterning activity of Sonic hedgehog by secreted BMP inhibitors expressed by notochord and somites. Development 2000, 127, 4855-4866. [PubMed]

93. Dutton, R.; Yamada, T.; Turnley, A.; Bartlett, P.F.; Murphy, M. Sonic hedgehog promotes neuronal differentiation of murine spinal cord precursors and collaborates with neurotrophin 3 to induce Islet-1. J. Neurosci. 1999, 19, 2601-2608. [PubMed]

94. Kucera, J.; Fan, G.; Jaenisch, R.; Linnarsson, S.; Ernfors, P. Dependence of developing group Ia afferents on neurotrophin-3. J. Comp. Neurol. 1995, 363, 307-320. [CrossRef] [PubMed]

95. Novitch, B.G.; Wichterle, H.; Jessell, T.M.; Sockanathan, S. A requirement for retinoic acid-mediated transcriptional activation in ventral neural patterning and motor neuron specification. Neuron 2003, 40, 81-95. [CrossRef] [PubMed]

96. Pons, S.; Marti, E. Sonic hedgehog synergizes with the extracellular matrix protein vitronectin to induce spinal motor neuron differentiation. Development 2000, 127, 333-342. [PubMed]

97. Pons, S.; Trejo, J.L.; Martinez-Morales, J.R.; Marti, E. Vitronectin regulates Sonic hedgehog activity during cerebellum development through CREB phosphorylation. Development 2001, 128, 1481-1492. [PubMed]

98. Fogarty, M.P.; Emmenegger, B.A.; Grasfeder, L.L.; Oliver, T.G.; Wechsler-Reya, R.J. Fibroblast growth factor blocks Sonic hedgehog signaling in neuronal precursors and tumor cells. Proc. Natl. Acad. Sci. USA 2007, 104, 2973-2978. [CrossRef] [PubMed]

99. Bluske, K.K.; Vue, T.Y.; Kawakami, Y.; Taketo, M.M.; Yoshikawa, K.; Johnson, J.E.; Nakagawa, Y. $\beta$-Catenin signaling specifies progenitor cell identity in parallel with Shh signaling in the developing mammalian thalamus. Development 2012, 139, 2692-2702. [CrossRef] [PubMed]

100. Tuson, M.; He, M.; Anderson, K.V. Protein kinase A acts at the basal body of the primary cilium to prevent Gli2 activation and ventralization of the mouse neural tube. Development 2011, 138, 4921-4930. [CrossRef] [PubMed]

101. Reimer, M.M.; Norris, A.; Ohnmacht, J.; Patani, R.; Zhong, Z.; Dias, T.B.; Kuscha, V.; Scott, A.L.; Chen, Y.C.; Rozov, S.; et al. Dopamine from the brain promotes spinal motor neuron generation during development and adult regeneration. Dev. Cell 2013, 25, 478-491. [CrossRef] [PubMed]

102. Kong, J.H.; Yang, L.; Dessaud, E.; Chuang, K.; Moore, D.M.; Rohatgi, R.; Briscoe, J.; Novitch, B.G. Notch activity modulates the responsiveness of neural progenitors to Sonic hedgehog signaling. Dev. Cell 2015, 33, 373-387. [CrossRef] [PubMed]

103. Di Marcotullio, L.; Ferretti, E.; Greco, A.; de Smaele, E.; Po, A.; Sico, M.A.; Alimandi, M.; Giannini, G.; Maroder, M.; Screpanti, I.; et al. Numb is a suppressor of Hedgehog signalling and targets Gli1 for Itch- dependent ubiquitination. Nat. Cell Biol. 2006, 8, 1415-1423. [CrossRef] [PubMed]

104. Imayoshi, I.; Sakamoto, M.; Yamaguchi, M.; Mori, K.; Kageyama, R. Essential roles of Notch signaling in maintenance of neural stem cells in developing and adult brains. J. Neurosci. 2010, 30, 3489-3498. [CrossRef] [PubMed]

105. Stasiulewicz, M.; Gray, S.D.; Mastromina, I.; Silva, J.C.; Bjorklund, M.; Seymour, P.A.; Booth, D.; Thompson, C.; Green, R.J.; Hall, E.A.; et al. A conserved role for Notch signaling in priming the cellular response to Shh through ciliary localisation of the key Shh transducer Smo. Development 2015, 142, 2291-2303. [CrossRef] [PubMed]

106. Lee, J.; Platt, K.A.; Censullo, P.; Ruiz i Altaba, A. Gli1 is a target of Sonic hedgehog that induces ventral neural tube development. Development 1997, 124, 2537-2552. [PubMed]

107. Belgacem, Y.H.; Borodinsky, L.N. Inversion of Sonic hedgehog action on its canonical pathway by electrical activity. Proc. Natl. Acad. Sci. USA 2015, 112, 4140-4145. [CrossRef] [PubMed] 
108. Villavicencio, E.H.; Walterhouse, D.O.; Iannaccone, P.M. The Sonic hedgehog-Patched-Gli pathway in human development and disease. Am. J. Hum. Genet. 2000, 67, 1047-1054. [CrossRef]

109. Pietsch, T.; Waha, A.; Koch, A.; Kraus, J.; Albrecht, S.; Tonn, J.; Sorensen, N.; Berthold, F.; Henk, B.; Schmandt, N.; et al. Medulloblastomas of the desmoplastic variant carry mutations of the human homologue of Drosophila patched. Cancer Res. 1997, 57, 2085-2088. [PubMed]

110. Stecca, B.; Ruiz i Altaba, A. Brain as a paradigm of organ growth: Hedgehog-Gli signaling in neural stem cells and brain tumors. J. Neurobiol. 2005, 64, 476-490. [CrossRef] [PubMed]

111. Schuller, U.; Heine, V.M.; Mao, J.; Kho, A.T.; Dillon, A.K.; Han, Y.G.; Huillard, E.; Sun, T.; Ligon, A.H.; Qian, Y.; et al. Acquisition of granule neuron precursor identity is a critical determinant of progenitor cell competence to form Shh-induced medulloblastoma. Cancer Cell 2008, 14, 123-134. [CrossRef] [PubMed]

112. Yang, Z.J.; Ellis, T.; Markant, S.L.; Read, T.A.; Kessler, J.D.; Bourboulas, M.; Schuller, U.; Machold, R.; Fishell, G.; Rowitch, D.H.; et al. Medulloblastoma can be initiated by deletion of Patched in lineage-restricted progenitors or stem cells. Cancer Cell 2008, 14, 135-145. [CrossRef] [PubMed]

113. Swartling, F.J.; Savov, V.; Persson, A.I.; Chen, J.; Hackett, C.S.; Northcott, P.A.; Grimmer, M.R.; Lau, J.; Chesler, L.; Perry, A.; et al. Distinct neural stem cell populations give rise to disparate brain tumors in response to N-MYC. Cancer Cell 2012, 21, 601-613. [CrossRef] [PubMed]

114. Flora, A.; Klisch, T.J.; Schuster, G.; Zoghbi, H.Y. Deletion of Atoh1 disrupts Sonic hedgehog signaling in the developing cerebellum and prevents medulloblastoma. Science 2009, 326, 1424-1427. [CrossRef] [PubMed]

115. Forget, A.; Bihannic, L.; Cigna, S.M.; Lefevre, C.; Remke, M.; Barnat, M.; Dodier, S.; Shirvani, H.; Mercier, A.; Mensah, A.; et al. Shh signaling protects Atoh1 from degradation mediated by the E3 ubiquitin ligase Huwe1 in neural precursors. Dev. Cell 2014, 29, 649-661. [CrossRef] [PubMed]

116. He, X.; Zhang, L.; Chen, Y.; Remke, M.; Shih, D.; Lu, F.; Wang, H.; Deng, Y.; Yu, Y.; Xia, Y.; et al. The G protein $\alpha$ subunit $\mathrm{G} \alpha \mathrm{s}$ is a tumor suppressor in Sonic hedgehog-driven medulloblastoma. Nat. Med. 2014, 20, 1035-1042. [CrossRef] [PubMed]

117. Berman, D.M.; Karhadkar, S.S.; Hallahan, A.R.; Pritchard, J.I.; Eberhart, C.G.; Watkins, D.N.; Chen, J.K.; Cooper, M.K.; Taipale, J.; Olson, J.M.; et al. Medulloblastoma growth inhibition by hedgehog pathway blockade. Science 2002, 297, 1559-1561. [CrossRef] [PubMed]

118. Oliver, T.G.; Read, T.A.; Kessler, J.D.; Mehmeti, A.; Wells, J.F.; Huynh, T.T.; Lin, S.M.; Wechsler-Reya, R.J. Loss of patched and disruption of granule cell development in a pre-neoplastic stage of medulloblastoma. Development 2005, 132, 2425-2439. [CrossRef] [PubMed]

119. Pazzaglia, S.; Tanori, M.; Mancuso, M.; Gessi, M.; Pasquali, E.; Leonardi, S.; Oliva, M.A.; Rebessi, S.; di Majo, V.; Covelli, V.; et al. Two-hit model for progression of medulloblastoma preneoplasia in Patched heterozygous mice. Oncogene 2006, 25, 5575-5580. [CrossRef] [PubMed]

120. Mille, F.; Tamayo-Orrego, L.; Levesque, M.; Remke, M.; Korshunov, A.; Cardin, J.; Bouchard, N.; Izzi, L.; Kool, M.; Northcott, P.A.; et al. The Shh receptor Boc promotes progression of early medulloblastoma to advanced tumors. Dev. Cell 2014, 31, 34-47. [CrossRef] [PubMed]

121. Crome, L.; Cowie, V.; Slater, E. Statistical Note on Cerebellar and Brain-Stem Weight in Mongolism. J. Ment. Defic. Res. 1966, 10, 69-72. [CrossRef]

122. Baxter, L.L.; Moran, T.H.; Richtsmeier, J.T.; Troncoso, J.; Reeves, R.H. Discovery and genetic localization of Down syndrome cerebellar phenotypes using the Ts65Dn mouse. Hum. Mol. Genet. 2000, 9, 195-202. [CrossRef] [PubMed]

123. Olson, L.E.; Roper, R.J.; Baxter, L.L.; Carlson, E.J.; Epstein, C.J.; Reeves, R.H. Down syndrome mouse models Ts65Dn, Ts1Cje, and Ms1Cje/Ts65Dn exhibit variable severity of cerebellar phenotypes. Dev. Dyn. 2004, 230, 581-589. [CrossRef] [PubMed]

124. Roper, R.J.; Baxter, L.L.; Saran, N.G.; Klinedinst, D.K.; Beachy, P.A.; Reeves, R.H. Defective cerebellar response to mitogenic Hedgehog signaling in Down's syndrome mice. Proc. Natl. Acad. Sci. USA 2006, 103, 1452-1456. [CrossRef] [PubMed]

125. Trazzi, S.; Mitrugno, V.M.; Valli, E.; Fuchs, C.; Rizzi, S.; Guidi, S.; Perini, G.; Bartesaghi, R.; Ciani, E. APP-dependent up-regulation of Ptch1 underlies proliferation impairment of neural precursors in Down syndrome. Hum. Mol. Genet. 2011, 20, 1560-1573. [CrossRef] [PubMed]

126. Das, I.; Park, J.M.; Shin, J.H.; Jeon, S.K.; Lorenzi, H.; Linden, D.J.; Worley, P.F.; Reeves, R.H. Hedgehog agonist therapy corrects structural and cognitive deficits in a Down syndrome mouse model. Sci. Transl. Med. 2013, 5, 201ra120. [CrossRef] [PubMed] 
127. Akazawa, C.; Tsuzuki, H.; Nakamura, Y.; Sasaki, Y.; Ohsaki, K.; Nakamura, S.; Arakawa, Y.; Kohsaka, S. The upregulated expression of Sonic hedgehog in motor neurons after rat facial nerve axotomy. J. Neurosci. 2004, 24, 7923-7930. [CrossRef] [PubMed]

128. Reimer, M.M.; Kuscha, V.; Wyatt, C.; Sorensen, I.; Frank, R.E.; Knuwer, M.; Becker, T.; Becker, C.G. Sonic hedgehog is a polarized signal for motor neuron regeneration in adult zebrafish. J. Neurosci. 2009, 29, 15073-15082. [CrossRef] [PubMed]

129. Sirko, S.; Behrendt, G.; Johansson, P.A.; Tripathi, P.; Costa, M.; Bek, S.; Heinrich, C.; Tiedt, S.; Colak, D.; Dichgans, M.; et al. Reactive glia in the injured brain acquire stem cell properties in response to Sonic hedgehog. Cell Stem Cell 2013, 12, 426-439. [CrossRef] [PubMed]

130. Amankulor, N.M.; Hambardzumyan, D.; Pyonteck, S.M.; Becher, O.J.; Joyce, J.A.; Holland, E.C. Sonic hedgehog pathway activation is induced by acute brain injury and regulated by injury-related inflammation. J. Neurosci. 2009, 29, 10299-10308. [CrossRef] [PubMed]

131. Chechneva, O.V.; Mayrhofer, F.; Daugherty, D.J.; Krishnamurty, R.G.; Bannerman, P.; Pleasure, D.E.; Deng, W. A Smoothened receptor agonist is neuroprotective and promotes regeneration after ischemic brain injury. Cell Death Dis. 2014, 5, e1481. [CrossRef] [PubMed]

132. Samanta, J.; Grund, E.M.; Silva, H.M.; Lafaille, J.J.; Fishell, G.; Salzer, J.L. Inhibition of Gli1 mobilizes endogenous neural stem cells for remyelination. Nature 2015, 526, 448-452. [CrossRef] [PubMed]

(c) 2016 by the authors; licensee MDPI, Basel, Switzerland. This article is an open access article distributed under the terms and conditions of the Creative Commons Attribution (CC-BY) license (http:/ / creativecommons.org/licenses/by/4.0/). 